\title{
Elusive retributive justice in post-Khmer Rouge Cambodia: Challenges of using ECCC Victim Information Forms as a victim participatory rights mechanism
}

\author{
Leakhena Nou, PhD*
}

\begin{abstract}
This paper focuses on the procedural challenges of using the Victim Information Forms (VIFs) to analyze survivors' experiences with the Extraordinary Chambers in the Courts of Cambodia (ECCC), commonly known as the Khmer Rouge Tribunal. The paper takes a systematic public/medical sociology approach to examining the VIF as a participatory rights mechanism for victims wishing to pursue justice for themselves and their loved ones who experienced the Khmer Rouge atrocities, torture, forced relocation, starvation, forced labor, rape, robbery, and other physical and psychological torment, firsthand. It provides the first comparative, critical analysis of both the original VIF and the revised form issued midway through the submission period; both forms appear as appendices to the paper. Conclusions are
\end{abstract}

\footnotetext{
${ }^{\star}$ Department of Sociology, California State University, Long Beach

i The original and revised VIFs can be found in Appendix A and B, respectively.

ii For additional information about the ECCC, see: http://www.eccc.gov.kh/en/about-eccc and http://www.cambodiatribunal.org/
}

Correspondence: leakhena.nou@csulb.edu drawn and suggestions made by the researcher based on the firsthand collection and submission of the largest group of VIFs from any single source around the world (outside of Cambodia itself), as well as on support work with victims/survivors during the ECCC proceedings in Phnom Penh, Cambodia in 2013.

Keywords: Posttraumatic Stress Disorder, depression, mental health, human rights, social recovery, Extraordinary Chambers in the Courts of Cambodia

\section{Introduction}

This paper focuses on the procedural challenges of using the Victim Information Forms (VIFs) ${ }^{i}$ to analyze survivors' experiences with the Extraordinary Chambers in the Courts of Cambodia (ECCC), commonly known as the Khmer Rouge Tribunal. ${ }^{\text {ii }}$

The paper takes a systematic public/ medical sociology approach to examining the VIF as a participatory rights mechanism in the ECCC for victims wishing to pursue justice for themselves and their loved ones who experienced the Khmer Rouge atrocities firsthand. The ECCC focuses on retributive justice as it seeks individual accountability 
and punishment, usually in the form of a criminal trial. Restorative justice, on the other hand, refers to promoting reconciliation between survivors and perpetrators. The research participants hoped to achieve both types of justice through filing VIFs and participating in the ECCC's proceedings in some way. This type of participation provides survivors with the comfort of knowing their voices have been heard and that history will know of their suffering. For many survivors, these are critical components of both their ongoing process of healing and their struggle to reconcile the past with the present and build a stronger Cambodia where genocide will never occur again.

A trademark of the ECCC is its inclusion of victims' testimonies as evidence for the prosecution. The court and other officials see this inclusion as a way to achieve justice and reconciliation for victims/survivors of the Khmer Rouge genocide (1975-79). This work is, in large part, the responsibility of the ECCC's Victims Support Section (VSS). ${ }^{\text {iii }}$

However, despite the ECCC's good intentions of including and recognizing victims in its trial proceedings, the court failed to provide concrete procedural assistance to victims/survivors for completing and submitting the VIF, which was especially problematic for overseas survivors who were far removed (both psychologically and geographically) from the ECCC. This was true in Case 001 (the trial of Kaing Guek Eav, alias Duch, former Commandant of Tuol Sleng, S-21), Case 002 (the trial of the

\footnotetext{
iii As the structure and process of the ECCC evolved over time, so did the name of the unit that worked with victims/survivors. For accuracy, this paper uses the correct terms in use at each point in time; for general purposes, however, the terms Victims Support Section, VSS, and Victims Unit are more or less interchangeable. For more information on the VSS, see: http:/www.eccc.gov.kh/ en/victims-support.
}

senior leaders of the Khmer Rouge, including Nuon Chea, alias Brother No. 2, former Deputy Secretary of the Central Committee and Member of the Standing Committee; Khieu Samphan, former Head of State; and Ieng Sary, former Minister of Foreign Affairs and his late wife Ieng Thirith, former Minister of Social Affairs), ${ }^{\text {iv }}$ and is likely to be problematic in the forthcoming Cases 003 and 004 (in which the defendants' identities have been kept confidential by the ECCC). ${ }^{1}$

The complex VIF is particularly difficult for elderly Cambodians living overseas who often do not have computer skills or access to the internet, nor the literacy skills to successfully complete the VIF on their own.

These technological and educational challenges are exacerbated by the logistical challenge of living thousands of miles away from the ECCC and not being able to take full advantage of the VSS. Combined, these challenges put the Cambodian diaspora at a marked disadvantage, as discussed in greater detail in a recent paper by this author ${ }^{2}$ and in a report by Khan, Korman, and Serna (under the direction of David Kaye) at the UCLA International Justice Clinic. ${ }^{3}$

While victim participation in the ECCC via submission of VIFs appears to be a practical and effective mechanism from the perspective of the ECCC, the form itself and its contents raise concerns about the judicial process. This paper focuses specifically on the VIF as a source of relevant information about victims/survivors, details of the crimes they claim to have endured during the genocide, and where and when those crimes allegedly took place. All of these categories of

\footnotetext{
iv Ieng Thirith was found to be mentally unfit to stand trial, and was ordered released in September 2012; she died in August 2015. Ieng Sary died in March 2013.
} 
information are requested by the Court in both the original and revised versions of the VIF issued by the ECCC.

This paper is rooted in the author's hands-on experience helping the Cambodian American diaspora community navigate the labyrinthine process of formally filing their VIFs (or testimonies) for Case 002 to the ECCC. This work with those filing their VIFs grew into the Cambodian Diaspora Victims' Participation Project (CDVPP), launched in 2009 under the auspices of the Applied Social Research Institute of Cambodia (ASRIC). The CDVPP took a public/medical sociological approach to engaging victims/ survivors in the judicial process, beginning with Case 002. ${ }^{v}$

The author's work was supported by her team of volunteers/community leaders, students, and legal professionals from UCLA and Harvard law schools. The author and her team worked tirelessly to inform the Cambodian American diaspora about their ability to participate in the ECCC, and to encourage them to take advantage of this unique historical opportunity. At that time (2009), no formal training or resources were provided by the ECCC for individuals living abroad and wishing to participate.

In their report on lessons learned about the Cambodian American diaspora community in the ECCC, Khan, Korman, and Serna ${ }^{3}$ highlighted the following considerations:

- Up to that time, the Court's outreach efforts to the Cambodian American diaspora had been inadequate.

- The process of filing as a civil party is largely unworkable; the Court's desire to involve as many victims as fully as possible in the courtroom trials becomes a

\footnotetext{
$\checkmark$ For more information on the CDVPP, see: http://www.asricjustice.com
}

logistical nightmare for a Court trying to conduct hearings in a time-efficient way.

- The notion of including victims in the proceedings is both highly commendable and popular in the international legal and human-rights communities.

- The process of how to include victims' testimonies needs to be streamlined-and planned and communicated with all parties well in advance of any filing deadlines; it is unfair to the victims to be unclear and/or inconsistent about the logistics of their participation in the proceedings. ${ }^{\mathrm{vi}}$

- The related challenges of victim inclusion and the need for timely trial proceedings need to be balanced for the sake of all concerned parties, especially victims and defendants.

Because of the lack of procedural support from the ECCC at the time of testimonial collection in 2009, the team had to figure things out along the way. After much struggle, we managed to finish gathering testimonies from the Cambodian American witnesses and then ensured the testimonials adhered to the Court's requirements. This was done with the expertise of our legal advisors and Professor David Kaye and his law students.

\footnotetext{
vi The ECCC's directions to victim participants were late in coming and the logistical details of filing changed frequently (even within days of the filing deadline), and such changes were not communicated in any consistent or effective manner. As a report by Khan, Korman, and Serna noted, "but for ASRIC's work, there may have been little independent communication with the CambodianAmerican community. Though the costs of sending representatives to the US. would likely be prohibitive, the Court could still communicate with Cambodian community groups in the US. and elsewhere, and not have to rely on the proactive work of outside organizations to facilitate this communication."3
} 
Figure 1: Profile of victim information forms submitted

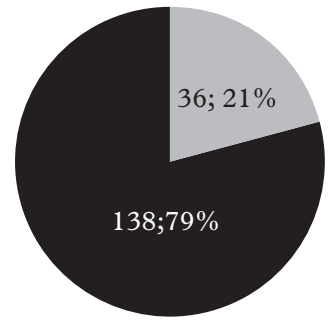

Old VIF New VIF

ASRIC submitted the largest collection of VIFs in the United States, with a $100 \%$ acceptance rate by the ECCC of ASRICfiled Civil Party and Complainant applications. In total, there were 8,202 VIFs submitted to the ECCC for Case 002 from all sources around the world. Of these, 3,988 were Civil Party applications, of which 3,866 were accepted. There were 4,214 Complainants. Among all Civil Party and Complainant applications, about $3.3 \%$ were from individuals living outside of Cambodia.

ASRIC had a total of 170 applications accepted: 41 Civil Party applications and 129 Complainant applications, and four additional Civil Parties joined ASRIC when their legal counsel could no longer represent them. The survivors who filed through ASRIC were represented by the legal staff at the Center for Justice and Accountability (CJA). Among the 8,202 VIFs received by the ECCC, 183 were from the United States (US): 52 Civil Party

Figure 2: Profile of applicants' sex

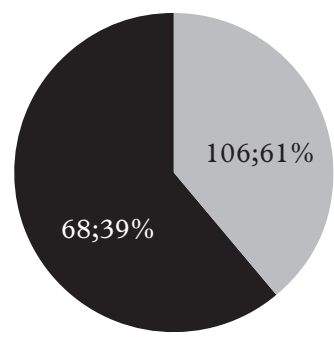

Female Male applications (representing just $0.017 \%$ of the total US Cambodian population) and 131 Complainant applications $(0.043 \%$ of the total US Cambodian population). ${ }^{2}$ Although the majority of applicants submitting VIFs to the ECCC live in Cambodia, this paper offers a rare look at survivor-applicants in one part of the diaspora, which has (as a whole) largely been ignored by the ECCC. Thus, the study offers a salient contribution to the global study of victim participation in the ECCC and international law more broadly.

Ensuring all information on the VIFs was accurate was a top priority for the research team, which included a skilled, often bilingual (Khmer and English), highly committed international team of research assistants, legal advisors, law professors and students, human rights experts, local partners in the United States and Cambodia, and individual contacts within the ECCC. This painstaking and highly sensitive process is presented in greater detail in another work by this author. ${ }^{2}$

Unfortunately, after having collected the Case 002 VIFs from the Cambodian American diaspora and submitting them to the Court by the January 2010 deadline, the author discovered that there were two versions of the VIF vii - a change that had not been communicated clearly by the ECCC. This is one example of a procedural oversight by the ECCC at the cost of the victims/survivors, as pointed out by the UCLA team, "the ECCC's victim participation process has been ad hoc, and the Court has had to adjust its rules and procedures as the proceedings commenced, to the detriment of victims." 3

Figure 1 shows that a majority of our applicants completed the old VIF instead of the new one. Out of 174 applicants there were $138(79 \%)$ who completed the old VIF versus $36(21 \%)$ who completed the new VIF. Although the older VIFs were accepted by the Court, an important question was 
missing (and later added to the newer version): applicants who completed the old VIF were not asked whether they feared for their safety when filing a VIF form.

Figures 2 and 3 illustrate the distribution of the applicants' sex and age, respectively. There were 106 females $(61 \%)$ and 68 males (39\%) (see Figure 2), and the highest percentage of applicants were between 61 and 70 years of age (see Figure 3). The mean age for the applicants in 2012 was 61 years old, falling within the range of 36 to 93 years. This data clearly shows that a majority of the applicants are elderly, and likely to have difficulty completing the VIF due to their lack of technical, linguistic and legal skills, and their age-related memory problems.

Even though the ECCC provides a rare opportunity for victims to participate in the judicial process by way of the VIF submission, it inadequately guided Cambodians in Cambodia and overseas in the step-by-step process of filling out the VIF, and left these applicants unaware of changes to the Court's rules and procedures regarding victim participation, as explored in a growing body of research. ${ }^{4-11}$ The work of identifying, understanding, and addressing this challenge was left to the author and her team. According to Mey, the same hurdles were faced by Cambodians living in France and Belgium. $^{12}$

One of the major challenges of assisting victim/survivors in completing their VIFs is helping them understand and make a choice regarding the option of filing either as a Civil Party or as a Complainant. In order to participate in the trials, individuals needed to qualify as victims, which the Practice Direction on Victim Participation ${ }^{13}$ defines (in brief) as any person or legal entity that has suffered harm as a result of the crimes heard by the ECCC. Victims were further divided into two distinct categories:
Figure 3: Profile of applicants' age in 2012

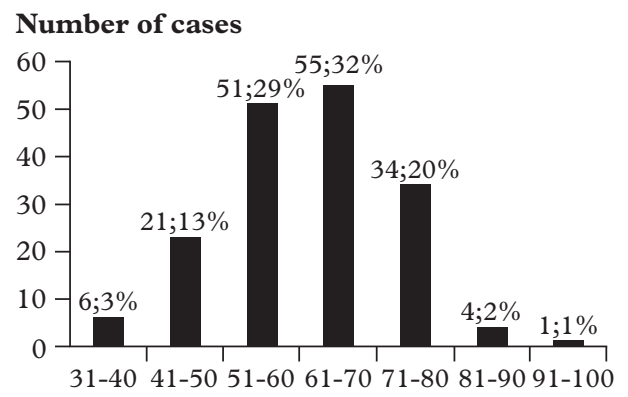

Age range

1. Civil Parties: Individuals filing as Civil Parties must be able to produce evidence that they have suffered physical, psychological, or material harm as a direct result of the alleged crimes for which the defendants are on trial. Civil Parties are official parties to the case, which affords them the right to assist the prosecution as well as to request investigations into certain matters. Civil Parties may also request "moral and collective" reparations if the defendants are found guilty. Civil Parties are at times called to testify in the Court proceedings.

2. Complainants: Individuals classified as Complainants are those whose VIFs contained information useful to the Court regarding the crimes allegedly committed by the Khmer Rouge. Complainants do not participate as parties in hearings as plaintiffs or defendants, and are not entitled to ask the court for reparations. They may, however, be asked to give evidence or testify as witnesses.

\section{Differences between the old and new victim information forms}

The section below discusses and compares the differences between the original VIF and the revised form that replaced it. ${ }^{\text {vii }}$

\footnotetext{
vii The original and revised forms can be found
} in Appendix A and Appendix B, respectively. 
Changes made in the revised VIF:

PART A - Personal information about the victim

One of the more visually obvious additions

to the revised VIF was extra space provided

for items 1 and items 7 to 10 , which ask for

the applicant's full name, nationality,

occupation, and father and mother's names.

While the additional space is welcome here, sections that called for descriptions of, or reasons for, an applicant's response were not given the appropriate space. In addition, the revised VIF included a space for the applicant's name in the Khmer language, as well as all other names ever used, in both English and in Khmer. This change was particularly important for individuals who took English names when they left Cambodia; the additional information enables the ECCC to find other individuals who might be able to corroborate the applicants' testimonies, but only if the applicants could be identified by the original, Cambodian names they used in the period from 1975 to 1979 .

An applicant's place of birth was also requested in the revised form, and the new VIF made a clear distinction between an applicant's permanent address versus his/her present address. This addition allows applicants to include their current US address, as well as any Cambodian addresses they are associated with.

The Court needs to consider all three pieces of information (place of birth, permanent address, and current address) in order to clearly and accurately identify in-country applicants versus those from overseas when compiling the data on the submitted VIFs.

Part A of the revised VIF also includes a new item for means of contact. This change broadened applicants' options greatly regarding how they wished to be contacted. Applicants could choose to be contacted through an intermediary organization, the
Victims Association, an individual acting on their behalf, or a lawyer (either foreign or Cambodian). The original VIF had only two options for means of contact (via a lawyer or the Victims Association), which posed an additional disincentive to filing for many survivors, such as Sou Heng, who told us (Heng, Sou. Written statement to: ASRIC. 2009 October 03):

"Due to fear of retaliation from the government of Cambodia and safety of my relatives in Cambodia, I choose not to file. What my family and I went through is unimaginable. I lost more than 40 family members to the killing fields, including my parents. My husband was murdered by the KR in 1976. He was only 24 years old."

Given many survivors' pronounced wariness of governmental employees, police, and other "official people," having additional choices in this regard helped many applicants feel far more comfortable with the filing process.

The last question in Part A of both the original and revised VIFs asked applicants whether they had already submitted an application as either a civil party or complainant to the ECCC (yes/no). The revised VIF omits the original form's query regarding the place, date, and time when the applicant submitted the VIF. But perhaps the most significant difference between the two forms is that the revised VIF asks participants their reasons for filing, something the original form overlooked. Having the opportunity to answer this question was meaningful to many survivors, who saw participating in the ECCC as a way for them to heal on multiple levels. Consider, for example, the words of survivor Mam Yim (Yim, Mam.

Statement at: CDVPP Workshop. 2009

November 13): 
"No one should ever have to suffer the way [the Khmer people] did. It is very difficult to find words to fully describe the pain and anguish we have felt. It has been nearly 34 years, yet many of us continue to suppress our deepest thoughts and fears. However, in order for us to move forward and find some closure, we must stand up and speak out against those who have committed atrocities against humanity, like the Khmer Rouge. I feel that what ASRIC is doing is giving us a once-in-a-lifetime opportunity to confront our inner deepest fears. So I ask all of those who have endured the Khmer Rouge regime to overcome your fears and confront them once and for all."

In a similar vein, survivor Somrith Som strongly encouraged others to file (Som, Somrith. Statement at: CDVPP Workshop. 2009 November 13):

"Whether you decide to file or not, because you suffered that is reason enough to file. That should be enough for you to demand justice.

[.. .] Staying silent isn't going to bring about justice. [...] You have every right to be afraid and fearful. That is legitimate. But you are not alone -- you have a whole community of sufferers here together. Here we have the opportunity to share stories. It's not about who is on trial. The fact is that you're not happy. It's time for you to say that a group of people are responsible for this. Leave this as a legacy for my kids' grandkids: that this should not happen in the future."

Part B - Information about the alleged crimes Whereas the original VIF only asked applicants to provide details of the crime(s) committed against them, the revised VIF also asks applicants to explain why they believe the crimes took place. The newer form also asks applicants to indicate general location(s) where the alleged crimes took place (village, commune, district and province) instead of the more specific locations (village, district, area, and zone) requested in the original form.

This change is more important than it might appear to be as it is likely to be more difficult for applicants to recall the specific locations of alleged crimes, due not only to the applicants' advanced age, but also because the details of their forced transfers from one location to the next during the Khmer Rouge were kept from the victims. The revised VIF provides an increased opportunity for the crimes perpetuated against these individuals to be examined by the ECCC, and perhaps even for the ECCC to broaden the reach of the geographical area currently under consideration.

The descriptions were graphic and horrifying. A 49-year-old female applying as a Civil Party asked a translator to record that, "as punishment, they took her away, tied up her arms, tied her to a mango tree and blind-folded her. They forced a burning hot metal rod into her anus (the size of a pencil). The complainant was in constant torture and pain.” Another filer, a 59-yearold female, asked her translator to record that, "she was taken to a two-story house and was blindfolded with a white plastic bag over her head. It was tied around her neck to prevent her from breathing. She passed out and when she woke up she was in a bamboo field far away from where she had been taken to be tortured."

After describing the crimes in the new VIF, applicants are asked whether or not they were a victim of these crimes. The original VIF posed this as a simple yes/no question, but the revised VIF probes more deeply into the topic by asking applicants whether they knew of any other victims of these crimes, and if so to provide possible names and addresses (if living), if applicants were willing 
to do so. If applicants elected to disclose other possible victims' names, they had the option of keeping the person's identity anonymous or making it public. Applicants were also asked to provide other pertinent details that might help to identify the other people involved, including the person's current age (or age at death, if deceased), nationality, ethnicity, religion, and occupation. The revised VIF also asked if applicants had any relationship with the other victims: family, neighbor, friend, and so forth.

The revised VIF asked whether the applicant was a witness to the alleged crimes. If so, applicants were asked to describe other witnesses to these crimes, and to indicate whether those additional witnesses were still living and what, if any, relation there was between the applicant and the other witnesses. The original VIF asked similar questions but was more complicated; the revised VIF provides separate questions requiring only a yes/no response.

Finally, Part A of the revised VIF includes an entirely new question: applicants are asked whether they fear any specific negative consequences for themselves or for anyone named by them in the VIF as a result of completing the VIF and sending it to the ECCC. After answering this yes or no question they were asked to explain their fears in detail.

\section{Part C - Application to be joined as a civil party} Part C only applies to applicants wishing to file as a Civil Party to the judicial investigations being pursued at the ECCC (Case 002 for example). A serious problem with this section is the ECCC's failure to explain the costs and benefits of filing as a Civil Party.

This omission made it nearly impossible for applicants to make informed decisions on their own. Because of this, the author and her team had to educate the Cambodian diaspora about the mechanics of the ECCC, and explain the filing options and their associated costs and benefits. Clearly, it would have been preferable for the ECCC itself to provide such information to all applicants.

The revised VIF (Appendix B, Part C) attempts to explain the criteria for qualifying as a Civil Party as follows:

"In order for the Court to accept you as a Civil Party, the injury you suffered must be: a) physical, material, or psychological; b) the direct consequence of the offence, personal, and have actually come into being. If your claim does not prove your identity and provide sufficient detail on the harm you suffered, it may be rejected by the Court's judges. For information on the connection between this harm and the crimes being investigated by the ECCC that needs to be shown, please contact the Victims Support Section.”

What is meant by physical, material, or psychological harm or the specific crimes being considered by the ECCC are not detailed in the VIF. While collecting testimonials/VIFs from the Cambodian American diaspora in 2009, the author and her team were not provided with any additional information on the Court's procedural requirements, which made things difficult for everyone. The VIF failed to provide sufficient space for any details about crimes alleged, and there was no indication that details listed on an additional sheet of paper would be accepted by the Court.

The final question in Part $\mathrm{C}$ of the revised VIF asks Civil Party applicants whether they had any material or property loss. Applicants claiming such losses were asked to provide details or physical indicators that would help identify the extent of loss suffered. As indicated earlier, the space provided for such required details was woefully inadequate. 


\section{Part D - Signatures}

This last section in the VIF asks for applicants' signatures. The original VIF asked applicants to indicate whether they were filing as a witness, a Complainant, or a Civil Party by checking a box in this section. The revised VIF simplified the process by including all applicants as Complainants and only asking applicants to tick one box indicating whether they wished to be included as a Civil Party or not.

Another improvement in the revised VIF was the addition of dotted lines making it clear (to applicants and the people helping them) where applicants were expected to sign their names. The new VIF also added a line for applicants to include details (such as location and date) about the person acting on their behalf when submitting the VIF. These changes to the signatures section of the VIF were particularly important when we consider many applicants' lack of familiarity with official documents and precise legal requirements, and (in some cases) limited literacy in either Khmer or English.

\section{Additional omissions from the original form in the revised form:}

PART A - Personal information about the victim In order for applicants to submit a VIF, they must have a proof of identity. In the original VIF, applicants were provided with ten ways to satisfy this requirement: passport, driving license, identity card, letter from local authority, camp registration card, card from humanitarian agency, tax document, voting card, other, and none. The revised VIF did not include the option of using an unspecified "tax document" as proof of identity.

At the bottom of Part A, the original VIF included a section marked "FOR VICTIMS UNIT USE ONLY," which had a series of checkbox items that confused and distracted the applicants. This section does not appear in the revised VIF.

\section{Part D - Signatures}

The original VIF (on page 4, just above "NOTE") required applicants to include their fingerprint "in the first box in Part E" - yet the form had no Part E.

\section{Conceptual limitations of the VIF as an evidentiary victim participation mechanism in the ECCC}

One serious issue with the VIF is the lack of clearly defined and explained concepts in relation to the questions being asked of the applicants. For example, in the new VIF Part A, question 12, applicants are asked, "Have you ever had any disability or disabilities? If yes, please specify," yet no definition or examples of disabilities are provided. Many applicants were unsure about whether they were being asked about physical disabilities, mental disabilities, or both. Many Cambodians in the US diaspora indicated a combination of both physical and mental disabilities, either in their responses to this question or elsewhere in their narrative.

Applicants were also confused by Part C, questions 2 to 6 . Here, applicants were asked to describe the injury and harm suffered, indicate whether they had been examined by a doctor after the event(s) occurred, discuss any lingering mental or physical conditions, and so on. It was common for applicants who previously (in Part A, question 12) had indicated that they had no disability to be confused by this section; often, applicants included information about disabilities in this section even though they had indicated an absence of any disability earlier in the VIF.

The ECCC could have reduced the confusion in this section with clear, simple instructions indicating that only applicants who had claimed a disability in Part A, 
question 12 should complete Part C, questions 2 to 6 .

Additionally, the VIF lacked sufficient, specific guidance on what to include in the applicant's narrative testimonies requested in Part C. The additional text in the new VIF ("In order for the Court to accept you as a Civil Party, the injury you suffered must be: a) physical, material or psychological; b) the direct consequence of the offence, personal and have actually come into being") is a step in the right direction, but still leaves many applicants unsure about whether the harm they suffered qualifies them as Civil Party applicants. The authors of the VIF failed to consider the applicants' nearly universal inexperience with legal forms and the judicial process, and could have helped the applicants by providing concise, plain-language definitions of legal terms and a few examples of each type of injury.

Inadequate space for written responses was another problem plaguing applicants, many of whom assumed that they needed to answer each question in the space provided. Inconsistent instructions on the VIF added to the confusion. In Part $\mathrm{B}$, applicants are asked to write longer responses on a separate sheet of paper, but in Part C this instruction is not repeated. This inconsistency led many applicants to assume that their answers to Part C needed to fit within the tiny boxes provided. As a result of not being provided with specific instructions for all sections of the VIF, most diaspora applicants did not submit a narrative along with their VIF. The resulting loss of testimonial evidence is both judicially and historically devastating.

Finally, the VIF form closes by providing contact information for the Victims Support Section of the ECCC with the complete postal address, email address, and phone and fax numbers. Although under more typical circumstances this would seem adequate, a majority of the survivors in this research did not have an email address and in fact had no experience using the internet in any way. In addition, many people did not have the support of a more technologically fluent person (such as a child or grandchild) to assist them. One possible solution would be to provide a toll-free telephone support line offering bilingual applicant support during reasonable working hours in the US (or other countries with large survivor populations).

\section{Challenges in completing the VIF}

When presented with the VIF, applicants (especially those with limited education in English and/or Khmer) often had trouble understanding its complex legal and/or academic terms. Clearly, more highly educated applicants and those with more experience with the legal process, or applicants with such people on hand to assist them, were better able to understand and complete the form. For a typical applicant, completing the VIF proved very challenging regardless of whether they used the English or the Khmer version of the form.

Article 2.7 of the Victim Participation Practice Direction ${ }^{13}$ states that complaints filed shall not automatically initiate criminal prosecution. Instead, co-prosecutors reserve the privilege to decide, "Whether to reject the complaint, include the complaint in an ongoing preliminary investigation, conduct a new preliminary investigation, or forward the complaint directly to the Co-Investigating Judges." Furthermore, co-prosecutors can change their decision regarding any applicant's complaint at any time during the course of the trial. Thus all applicants run the risk of their complaints either not being accepted from the start, or initially being accepted and then later rejected. Many applicants found this situation intimidating and discouraging; they believed that if they 
filed a factual complaint that was accepted by the Court, it should not subsequently be rejected.

In Article 2.5 of the Victim Practice Direction ${ }^{13}$ the Victims Unit (now called the VSS) is described as existing to provide administrative assistance (but not financial or legal aid) to complainants in filing their complaints. This can become an issue for those applicants who do not have the necessary legal, linguistic, and/or technical abilities to complete and submit the form on their own, and who do not have access to an intermediary organization, a lawyer, or an individual acting on their behalf. To those unaided applicants, filling out the VIF seemed daunting and even impossible.

The Victim Practice Direction also fails to disclose other criteria that the Court is looking for when determining who becomes a Civil Party or who remains a Complainant: Location of crimes, specific years when the crimes must have taken place, and so on.

If applicants manage to receive Civil Party status, the instructions state that at that time the Victims Unit, which is the "sole contact for victims or their representatives for the filings necessary for participation in the proceedings," no longer plays a role in the legal proceedings. ${ }^{13}$ The Victims Unit/VSS may still provide assistance in resolving problems concerning the memberships of intermediary organizations, legal representation or protective measures, but it essentially leaves individuals not associated with an intermediary organization, lawyer, or individual acting on their behalf stranded to fend for themselves.

Article 4 states that, "Any victim participating in proceedings before the ECCC as a civil party has the right to be represented by a national lawyer, or a foreign lawyer in collaboration with a national lawyer." Although this does not technically preclude applicants from hiring lawyers earlier in the filing process, none of the applicants in this research was in a financial position to do so, and had to wait for a court-appointed lawyer to represent them. This was often a very long waiting process that resulted in being one of literally hundreds of cases assigned to a single lawyer.

Frequently, in order to address these overwhelming caseloads, individual cases were grouped together by type, e.g., widows, orphans, and so on. ASRIC's relationship with the staff of the Center for Justice and Accountability (CJA) ensured that all 45 survivors filing as Civil Parties received quality, individual legal representation. The 129 Complainants, who are a lower priority to the ECCC, also received legal support and informational updates through the CJA, most frequently via ASRIC. Getting this information to Complainants is critical because they are a low priority for the ECCC, and their legal needs are thus largely ignored.

Finally, Article 6 explains the filing, service, and notification documents process for individuals joined as Civil Parties. The instructions state that, "all filing, service and notification of documents relating to the case shall be done with the Greffier of the Office of the Co-Investigating Judges or the Chambers, as appropriate, through the Case File Officer, in accordance with the Practice Direction on filing of documents." Before applicants are Civil Parties, all information must first go through the Victims Unit.

However, when applicants become Civil Parties, the process becomes more convoluted, since Civil Parties then communicate with their lawyers, as well as with the Greffier of the Office of the Co-Investigating Judges or through a case file officer. All of this must be done within Cambodia, making it very difficult for international applicants such as those affiliated with ASRIC. 


\section{Discussion and conclusion}

The age of survivors was a major challenge to participating in the ECCC. More than $50 \%$ of the participants were over the age of 60 , making it difficult for many of them to access and keep abreast of the ECCC's activities and the participation process. With age comes the difficulty of remembering certain specific details in one's life, as well as difficulties in trying to communicate one's story in a foreign language (English).

Likewise, in general, the older the applicant, the more trouble they encountered trying to access the VIF online, filling out complicated and confusing forms, and sending the forms back to Cambodia. Without the assistance of ASRIC and its broad team of expert legal advisors, many of the applicants would not have been able to fill out the VIFs on their own.

A limitation of this study was the loss of valuable data when some of the collected VIFs were either scanned out of order or were mislabeled, which made it difficult to know which of the survivors had filed. Some of the scanned VIFs that included firsthand accounts of harm suffered were difficult to read due to poor penmanship coupled with low-resolution scans. Other forms were filled out in Khmer, and were also quite difficult to analyze due to the absence of a good translator, use of archaic language, and/or illegible handwriting. The VIFs from the few applicants who were not affiliated with ASRIC had a higher rate of errors or omissions. As previously noted, there were also a few instances where a VIF form was completed with either a short narrative of only a few sentences, or this section was left blank and had no narrative at all.

One of the biggest problems arose when we discovered that if applicants did not check the box (in Part C, question 1) indicating that they were applying for Civil Party status, they did not have the opportunity to describe the harm inflicted upon them. Only the applicants applying as a Civil Party had that opportunity, as they were asked to complete Part C. This represents a tremendous loss of data about the experiences of survivors filing as Complainants. For example, consider the testimony of Complainant \#4, noted in the cover letter ASRIC submitted to the ECCC along with the completed VIFs:

"This victim, a child when the Khmer Rouge took control of the country, witnessed her parents murdered in front of her. She visibly recalls her mother being taken off and shot and her father killed in front of her in the town of Phnom Dongrek. She was the only one from the 17 members of her family to survive the Khmer Rouge Regime. She was beaten and starved by Khmer Rouge soldiers, and on several occasions cruelly tortured.Victim \#4 describes one incident where nails were hammered into her arms, and another in which she was tortured with a hot metal rod. She eventually underwent surgery and had a metal rod inserted in her leg as a result of the torture she endured."

Part $\mathrm{C}$ is especially crucial as it gives survivors an opportunity to explain the nature of their psychological, physical, and material harm. Without this information, the VIF is far less powerful. Failure of the survivors to provide a description of the harm they suffered grants the ECCC de facto authority to assign cases into whatever crime categories it deemed most relevant. For example, the ECCC might include a case of forced rape (a separate crime category) under the general category of crimes against humanity.

During the collection of the testimonies, all of the survivors were assisted by community and law student volunteers who helped 
to document the applicants' stories. As a result, applicants relied on the volunteers' knowledge in order to complete the form correctly. In spite of making every effort to avoid them, there were still, potentially, instances in which language barriers may have led (directly or indirectly) to the loss of valuable information.

During testimonial collection, ASRIC and its volunteers had no detailed information on the specific crime sites and types of suffering that would be considered by the ECCC. Collecting the VIFs without such information from the ECCC made the data-collection process additionally challenging for all involved-ASRIC and its volunteers and the survivors who filed their testimonies.

There is much to learn from the ECCC's handling of the filing process for all applicants, those living in Cambodia, as well as those in communities around the world. The specific shortcomings of the original and revised VIFs discussed in this paper are pertinent not only to the Cambodian case, but also as cautionary tales to other post-conflict countries intending to include survivors of genocide, political violence, or human rights abuses in the pursuit of justice through victim participation in court proceedings.

Even with the best intentions of bringing the perpetrators to justice and including the victims in a meaningful way in that process, the ECCC faced unforeseen challenges. Some of these were successfully overcome, either in the original or in the revised VIF, while other challenges remained and threatened to undermine the impact of victim participation in the ECCC as a mechanism for both retributive and restorative justice. According to Un, "In the end, the ECCC is a politically negotiated and compromised search for justice." 4

In reality, no matter how effective the courts are in delivering justice, tenacious problems haunt Cambodians everywhere. These include a host of psychological issues including extremely high rates of depression, suicide, PTSD, addictions, and other self-destructive behaviors, many of which have trickled down through multiple generations. The mental health challenges are exacerbated by a long list of physical health problems, many of which are directly or indirectly attributable to surviving the Khmer Rouge genocide. Additionally, low rates of education, employment, and literacy (in any language) limit many Cambodians' ability to find their way out of the cycle of poor mental and physical health, debilitating economic poverty, and the overwhelming sense of loss stemming from the widespread perception that their once-thriving culture has been irreparably damaged. ${ }^{14-23}$

In spite of the ECCC's limitations, there are a number of benefits to participating survivors, as discussed in greater detail by Un. ${ }^{4}$ These include the unprecedented opportunity for survivors to augment the body of knowledge about the genocide from firsthand accounts: Information that serves all Cambodians and researchers of Cambodian history, now and in the future; the establishment of non-governmental organizations working for enhanced civic engagement, a benefit to citizens and an impediment to authoritarian regimes; and the public, physical manifestation of the international community's relentless fight for justice and accountability.

The problems plaguing Cambodians are multi-faceted and thus require a multifaceted response if justice and closure are to be attained. A forthcoming article will explore the more than 1,800 cases of alleged harm reported by this sample of 174 individuals in Case 002 (an average of just over 11 instances of harm per survivor), and 
provide a critical analysis of the patterned harmful exposure and traumatic consequences of the harm inflicted. Participation in the ECCC is a central factor for many survivors, and every effort should be made to make this process as productive as it can be for all parties. Because the VIF is the primary means for survivors to communicate with the ECCC, efforts to improve the form itself, and the support mechanisms behind it, will have a critical, positive, and significant impact on the trials and for genocide survivors throughout the diaspora.

Additional types of victim participation beyond the ECCC also warrant exploration. One such avenue is ASRIC's “Art as Witness" program, which served to engage survivors in sharing their stories outside of the ECCC, through visual art, music, and dance in small-scale workshops with professional artists, musicians, and dancers. ${ }^{\text {vii }}$

The victims/survivors themselves, naturally, should be the first source of additional ideas for ways to participate. Ideas generated by the present sample included trying the accused, holding them accountable, punishing the guilty parties, and establishing a rule of law in Cambodia.

Forward-looking suggestions were also put forth, such as asking the ECCC and the international community to establish international educational foundations to prevent "cultures of impunity," building a memorial at Tuol Sleng Prison, providing financial compensation for families, building meditation centers in the United States and Cambodia, requiring non-traditional/ non-Buddhist burials for the Khmer Rouge defendants, creating a local version of the South African Truth and Reconciliation model (which would bring together perpetra- tors and victims), providing educational opportunities and improved services to survivors, obtaining apologies from the Khmer Rouge and the government; and creating oral histories and personal memoirs of victimization, among other ideas. ${ }^{2}$

In many of these paths towards peace and justice, the best approach to promoting enhanced relationships and peace-building dialogue may well be a fusion of indigenous Cambodian approaches and Western-style dispute resolution techniques (such as reflective listening and rational conflict resolution processing). Gellman suggests that this could be a counterbalance to Cambodian conflict avoidance and emotion-focused behavioral styles. ${ }^{24}$

\section{Acknowledgments}

In addition to the expert advisors named in this paper, the author would also like to express her sincere gratitude to her research assistant, Alexandra Plassaras.

viii For more information on this program, see http://www.asricjustice.com/art-as-witness.html. 


\section{References}

1. Open Society Justice Initiative. Fact Sheet: Khmer Rouge leaders on trial. New York: Open Society Justice Initiative [Internet]. 2011 Nov 18. Available from: http://www.opensocietyfoundations.org/ sites/default/files/Case002-FactSheet.pdf

2. Nou L. Beyond Silent Suffering and Trauma Half a World Away: Participation of Cambodian Diaspora Genocide Survivors in the Extraordinary Chambers in the Courts of Cambodia. Asia Pacific World. Berghahn Books; 2013 Mar 1;4(1):56-79.

3. International Justice Clinic, UCLA School of Law [Internet]. Los Angeles: University of California. 2010 June. Available from: http://www.cja. org/downloads/ECCC\%20victims\%20participation\%20David\%20Kaye\%202009.pdf

4. Un K. The Khmer Rouge Tribunal: A Politically Compromised Search for Justice. The Journal of Asian Studies. Cambridge University Press (CUP); 2013 Oct 15;72(04):783-92.

5. Mohan M. The paradox of victim-centrism: victim participation at the Khmer Rouge Tribunal. International Criminal Law Review. Brill Academic Publishers; 2009 Dec 1;9(5):733-75.

6. Bonacker T, Form W, Pfeiffer D. Transitional justice and victim participation in Cambodia: A world polity perspective. Global Society. Informa UK; 2011 Jan;25(1):113-34.

7. Stensrud EE. New Dilemmas in Transitional Justice: Lessons from the Mixed Courts in Sierra Leone and Cambodia. Journal of Peace Research. SAGE Publications; 2009 Jan 1;46(1):5-15.

8. Yesberg K. Accessing justice through victim participation at the Khmer Rouge Tribunal. Law Rev. 2009;40(2):555-79.

9. McGonigle BN. Two for the price of one: attempts by the Extraordinary Chambers in the Courts of Cambodia to combine retributive and restorative justice principles. Leiden Journal of International Law. Cambridge University Press (CUP); 2009 Feb 4;22(01):127.

10. Rae JJ. War Crimes Accountability: Justice and reconciliation in Cambodia and East Timor? Global Change, Peace \& Security. Informa UK; 2003 Jun;15(2):157-78.

11. Williams S. The Cambodian Extraordinary Chambers: A dangerous precedent for international justice? Int and Comp Law Q. 2004 Jan;53(1):227-45.

12. Mey E. Briefing paper: Cambodian diaspora communities in transitional justice. New York: International Center for Transitional Justice. 2008 Mar.

13. ECCC Practice Direction on Victim Participation. 2007. [Internet]. Available from: http:// www.eccc.gov.kh/ default/files/legal-documents/ PD_Victims_Participation_rev1_En.pdf

14. Blair RG. Risk Factors Associated with PTSD and Major Depression among Cambodian Refugees in Utah. Health \& Social Work. Oxford University Press (OUP); 2000 Feb 1;25(1):23-30.

15. Bockers E, Stammel N, Knaevelsrud C. Reconciliation in Cambodia: Thirty Years After the Terror of the Khmer Rouge Regime. Torture. 2011;21(2):71-83.

16. Cheung P. Posttraumatic Stress Disorder Among Cambodian Refugees in New Zealand. Int J Soc Psychiatry. SAGE Publications; 1994 Mar 1;40(1):17-26.

17. Hinton DE, Chhean D, Pich V, Pollack MH, Orr SP, Pitman RK. Assessment of Posttraumatic Stress Disorder in Cambodian Refugees Using the Clinician-Administered PTSD Scale: Psychometric Properties and Symptom Severity. J Traumatic Stress. Wiley-Blackwell; 2006;19(3):405-9.

18. Fujii D, Yee BWK., Eap S, Kuoch T, Scully M. The neuropsychology of Cambodian Americans. In: Fujii D, editor. The neuropsychology of Asian Americans. New York (NY): Taylor \& Francis; 2011. 11-27 p.

19. Hinton DE, Rasmussen A, Nou L, Pollack MH, Good M. Anger, PTSD, and the nuclear family: A study of Cambodian refugees. Social Science \& Medicine. Elsevier BV; 2009 Nov;69(9):1387-94.

20. Marshall GN, Schell TL, Elliott MN, Berthold SM, Chun C. Mental health of Cambodian refugees two decades after resettlement in the United States. JAMA. American Medical Association (AMA); 2005 Aug 3;294(5):571.

21. Nou L. A qualitative examination of the psychosocial adjustment of Khmer refugees in three Massachusetts communities [Internet]. Occasional papers, Institute for Asian American Studies. Boston: University of Massachusetts. 2006. Available from: http://docs.lib.purdue.edu/cgi/ viewcontent . cgi?article $=1001 \&$ context $=$ jsaaea

22. Nou L. A sociological analysis of the psychosocial adaptation of Khmer refugees in Massachusetts. In Dalla RL, DeFrain J, Johnson J, Abbott DA, editors. Strengths and challenges of new immigrant families: Implications for research, theory, education, and service. Lexington (MA): Lexington Press; 2009. p. 33-51.

23. Stevens CA. Perspectives on the meanings of symptoms among Cambodian refugees. Journal of Sociology. SAGE Publications; $2001 \mathrm{Mar}$ 1;37(1):81-98.

24. Gellman M. 2008. No justice, no peace? National reconciliation and local conflict resolution in Cambodia. Asian Perspective. 2008;32(2):37-57. 


\section{Appendix A}

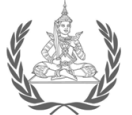

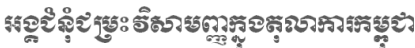

Extraordinary Chambers in the Courts of Cambodia

Chambres extraordinaires au sein des tribunaux cambodgiens

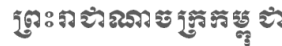

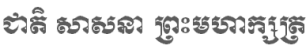

\section{Kingdom of Cambodia \\ Nation Religion King \\ Royaume du Cambodge Nation Religion Roi}

Appendix A

$\square \quad$ Office of the Co-Prosecutors

$\square \quad$ Office of the Co-Investigating Judges

Case File No:

Victim Information Form

PART A

PERSONAL INFORMATION ABOUT THE VICTIM

\begin{tabular}{|l|l|}
\hline 1. Name(s) and first name: & 2. Sex $\square$ Male $\quad \square$ Female \\
\hline 3. Place of Birth: & 4. Nationality: \\
\hline 5. Age/Date of Birth (if known dd/mm/yyyy): & 6. Occupation: \\
\hline 7. Marital Status $\square$ Single $\square$ Married $\square$ Divorced $\quad \square$ Widow/Widower $\quad \square$ Other \\
\hline 8. Father's or Tutor's Name: & Mother's Name: \\
\hline 9. How many dependants do you have? Please write number. \\
\hline $\begin{array}{l}\text { 10. Have you ever had any disability or disabilities? } \\
\text { If yes, please specify: }\end{array}$ \\
\hline 11. Which of the following proof of identity do you have? Please indicate the number. \\
\hline Type of proof of identity & Number or other reference \\
\hline$\square$ Passport & \\
\hline$\square$ Driver's licence & \\
\hline$\square$ Identity card (such as students, employees) & \\
\hline$\square$ Letter from Local Authority & \\
\hline$\square$ Camp registration card & \\
\hline$\square$ Card from humanitarian agency (such as UNHCR, WFP) & \\
\hline$\square$ Tax document & \\
\hline$\square$ Voting card & \\
\hline$\square$ Other & \\
\hline$\square$ None & \\
\hline
\end{tabular}

\section{FOR VICTIMS UNIT USE ONLY}

Application:

$\square$ Witness

$\square$ Complaint

$\square$ Civil Party Application

Action:

$\square$ Co-Prosecutors

$\square$ Co-investigating Judges 


\section{Appendix A}

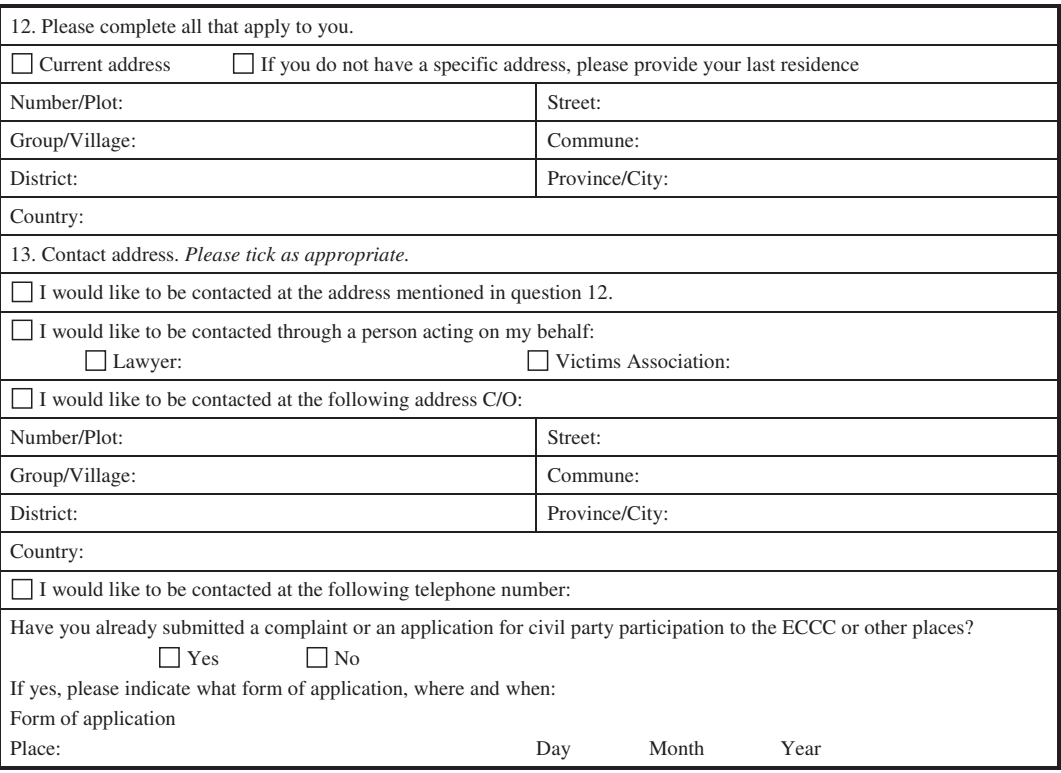

\section{PART B}

INFORMATION ABOUT THE ALLEGED CRIME(S)

Please attach answers to this section on a separate sheet of paper if necessary.

\begin{tabular}{|c|c|}
\hline \multicolumn{2}{|l|}{ 1. Please provide details of crime(s). } \\
\hline \multicolumn{2}{|l|}{ Location (village, district, area, zone ): } \\
\hline \multicolumn{2}{|l|}{ Date $(\mathrm{dd} / \mathrm{mm} / \mathrm{yyyy})$ : } \\
\hline \multicolumn{2}{|c|}{ Description of Crime(s) (what crimes occurred and how they occurred): } \\
\hline \multicolumn{2}{|c|}{$\begin{array}{l}\text { 2. Who do you believe is responsible for these crime(s) and why you believe this? } \\
\text { Please answer to the extent possible. }\end{array}$} \\
\hline 3. Were you a victim of these crime(s)? $\square$ Yes & $\square$ No \\
\hline 4. Were you a witness to these crime(s)? $\square$ Yes & $\square$ No \\
\hline $\begin{array}{l}\text { 5. Do you know any other victims or witnesses to the } \\
\text { (If yes (and if you can), please give their names and } \\
\text { would put the applicant or anyone else at risk): }\end{array}$ & $\begin{array}{l}\text { e(s)? } \quad \square \text { Yes } \quad \square \text { No } \\
\text { ses, unless you know that they wish to remain anonymous, or it }\end{array}$ \\
\hline
\end{tabular}




\section{Appendix A}

6. Do you have any relationship with these witnesses (are they family members, neighbours, friends, etc.)? $\square$ Yes $\square$ No (If yes, please indicate):

In order for Civil Party action to be admissible, the injury must be: a) physical, material or psychological; b) the direct consequence of the offence, personal and have actually come into being.

\section{$\underline{\text { PART C }}$}

APPLICATION TO BE JOINED AS A CIVIL PARTY

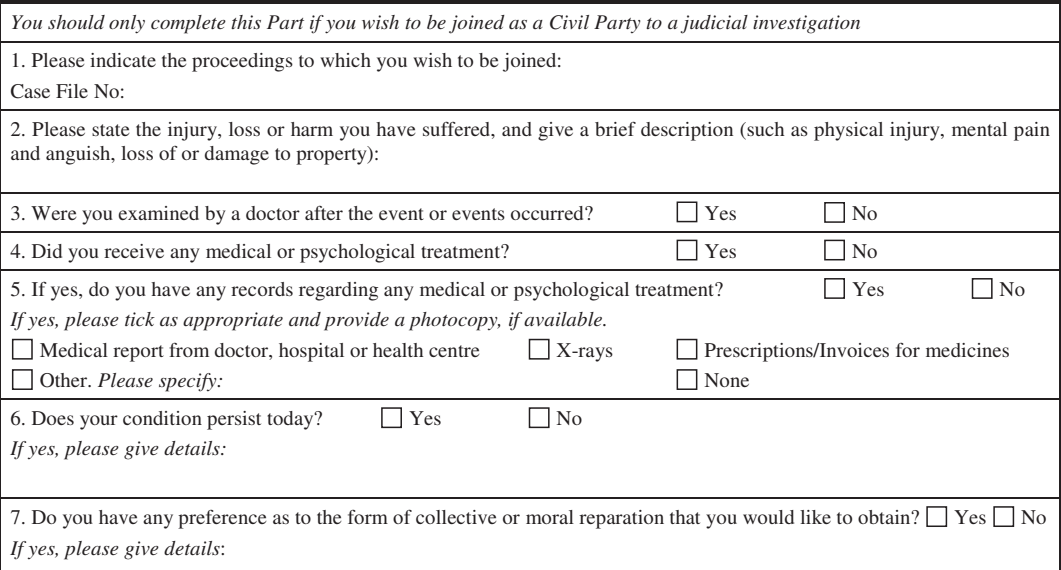

\section{$\underline{\text { PART D }}$}

\section{SIGNATURES}

1. SIGNATURE OF THE VICTIM
Please sign or add your fingerprint and date this Form, whether or not someone is acting on your behalf or assisting you in
filling in this Form.
I hereby declare that:
- To the best of my knowledge and belief, the information I have given in the present Form is correct, otherwise I will be
liable under the applicable law.
- I wish to participate in proceedings before the ECCC as: $\square$ a witness $\square$ a complainant
If you answered "civil party", please ensure that you have filled in Part C above
$\begin{aligned} & \text { Location: } \\ & \text { Day: } \\ & \text { Signature or fingerprint of the victim and name }\end{aligned}$
Witnessed by/Signature :
Signature: .................................................................




\title{
Appendix A
}

\author{
2. SIGNATURE OF THE PERSON ACTING ON BEHALF OF THE VICTIM AND CONSENT OF THE VICTIM \\ Consent of the victim: \\ I, \\ Print name of the victim \\ consent to \\ Print name of the person acting on behalf of the victim, in the capacity of \\ to act on my behalf in making this application. \\ Location: $\quad$ Day: Month: $\quad$ Year: \\ Signature or fingerprint of a person acting on behalf of the victim and name
}

Witnessed by/Signature:

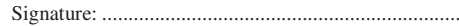

Before submitting this Application Form, please review it and tick the following as appropriate:

$\square$ I have attached the following documents in support of this Form:

1.

2.

3.

$\square$ I have signed or added my fingerprint on every page of this Form as well as any other documents accompanying it.

Please indicate total number of pages of this Form including additional pages and photocopies of documentation:

\begin{tabular}{||l|l|}
\hline \hline Victim: & Person acting on behalf of the victim: \\
\hline$\square \quad \begin{array}{l}\text { I have provided a photocopy of proof of } \\
\text { identity in response to Question 11 of Part A. }\end{array}$ & $\square$ I have signed or added my fingerprint on the second box in Part E. \\
$\begin{array}{l}\text { I have provided contact information in } \\
\text { response to Question 13 of Part A. }\end{array}$ \\
$\begin{array}{l}\text { I have signed or added my fingerprint on the } \\
\text { first box in Part E. }\end{array}$ \\
\hline
\end{tabular}

\section{NOTE}

Once the ECCC receives your Form, you will receive an acknowledgement. This acknowledgement will provide you with a registration number that you should use when communicating with the Court. If you send additional information to the Court, please use this registration number to ensure your application is properly updated. Please note that criminal proceedings take time and it may be a while before the ECCC judges make a decision on your application.

This Form and the process of applying are free of charge.

Victims Unit may be contacted at the address below or by email at victimsunit@eccc.gov.kh 


\section{Appendix B}

\section{Kingdom of Cambodia \\ Nation Religion King}

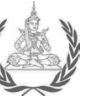

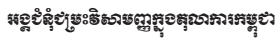

Extraordinary Chambers in the Courts of Cambodia

Chambres Extraordinaires au sein des Tribunaux Cambodgiens

Appendix A/Rev.1

Victim Information Form

PART A

PERSONAL INFORMATION ABOUT THE VICTIM

\begin{tabular}{|c|c|}
\hline \multicolumn{2}{|l|}{ 1. Name and first name: } \\
\hline \multicolumn{2}{|l|}{ 1.1. Name and first name in Khmer alphabet: } \\
\hline \multicolumn{2}{|l|}{ 2. All other name(s) ever used: } \\
\hline \multicolumn{2}{|l|}{ 2.1. All other name(s) ever used in Khmer alphabet: } \\
\hline 3. Sex: $\square$ Male $\square$ Female & 4. Place of Birth: \\
\hline 5. Age/Date of Birth (dd/mm/yyyy): & 6. Marital Status $\quad \square$ Married $\square$ Divorced \\
\hline$\square$ Please tick if date of birth is different from ID document & $\square$ Widow/Widower $\square$ Other: \\
\hline 7. Nationality: & 8. Occupation: \\
\hline 9. Father's or Tutor's Name: & 9.1. Name in Khmer alphabet: \\
\hline 10. Mother's Name: & 10.1. Name in Khmer alphabet: \\
\hline \multicolumn{2}{|l|}{ 11. How many dependants do you have? Please write number. } \\
\hline \multicolumn{2}{|l|}{$\begin{array}{l}\text { 12. Have you ever had any disability or disabilities? } \\
\text { If yes, please specify: }\end{array}$} \\
\hline \multicolumn{2}{|c|}{ 13. Which of the following proof of identity do you have? Please indicate the number and attach a photocopy. } \\
\hline Type of proof of identity & Number or other reference \\
\hline \multicolumn{2}{|l|}{$\square$ Identity card (also student or employee card) } \\
\hline \multicolumn{2}{|l|}{$\square$ Voting card } \\
\hline \multicolumn{2}{|l|}{$\square$ Letter from Local Authority } \\
\hline \multicolumn{2}{|l|}{$\square$ Driver's licence } \\
\hline \multicolumn{2}{|l|}{$\square$ Passport } \\
\hline \multicolumn{2}{|l|}{$\square$ Camp registration card } \\
\hline \multicolumn{2}{|l|}{$\square$ Card from humanitarian agency (such as UNHCR, WFP) } \\
\hline \multicolumn{2}{|l|}{$\square$ Other: } \\
\hline$\square$ None & \\
\hline
\end{tabular}

Victims Support Section, ECCC Information Centre, No. 6A, Street 21, Sangkat Tonle Basac I, Khan Chamcarmon, Phnom Penh, Cambodia, Email: vss@eccc.gov.kh, Tel: +(855) 023214 291, Fax: +(855) 023214295 


\section{Appendix B}

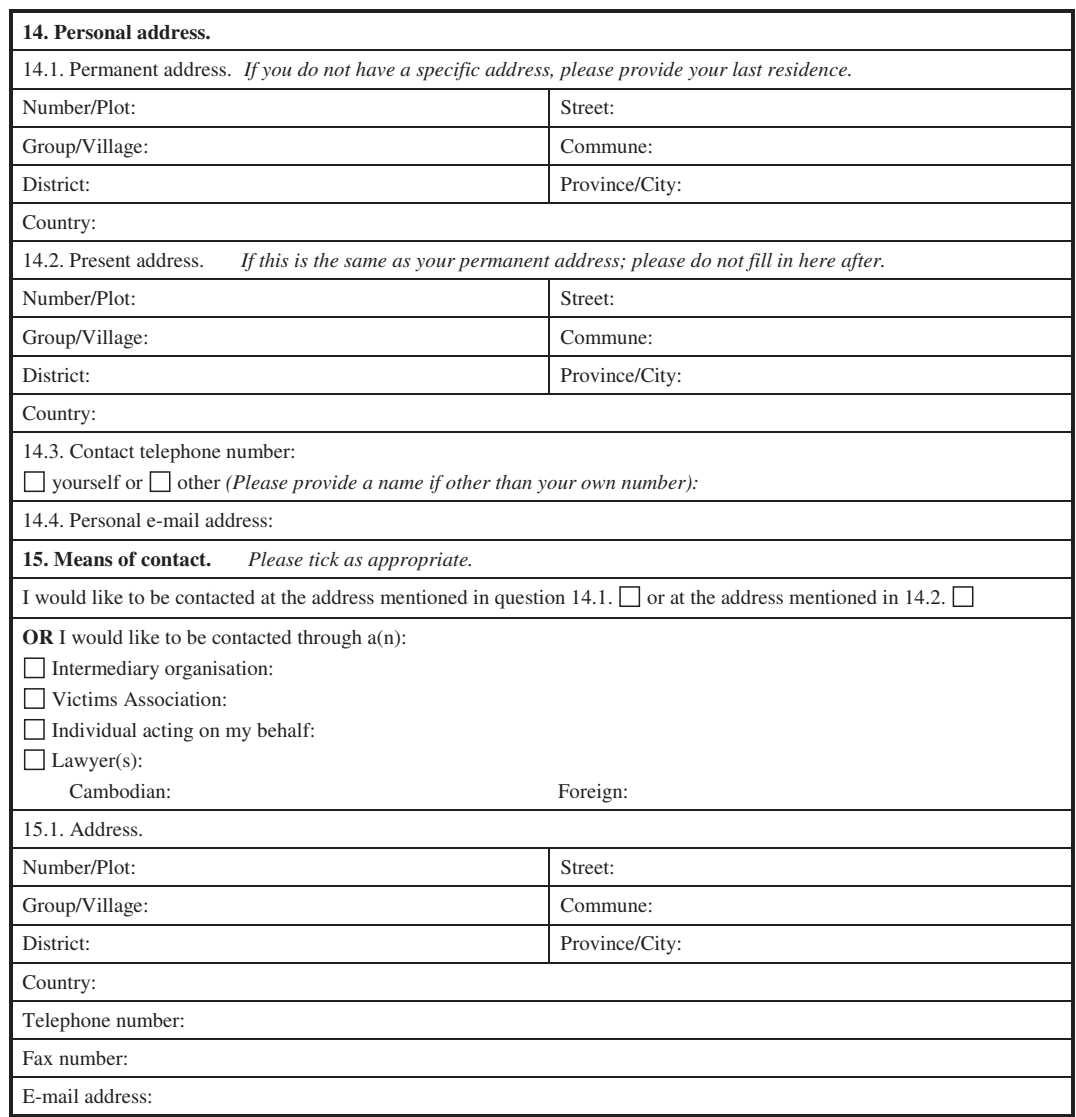




\title{
Appendix B
}

\author{
16. Have you already submitted a complaint or a Civil Party application to the ECCC? \\ $\square$ Yes $\quad \square$ No \\ If yes, please indicate the Victims Support Section registration number, the form of your participation, the place and date of \\ the submission; and indicate the reasons why you are now filling in a new Victim Information Form. \\ Registration number (if any): \\ Form of participation: \\ Place: \\ Day Month Year \\ Reasons for filling in a new form:
}

\section{PART B}

INFORMATION ABOUT THE ALLEGED CRIME(S)

Please attach answers to this section on a separate sheet of paper if necessary.

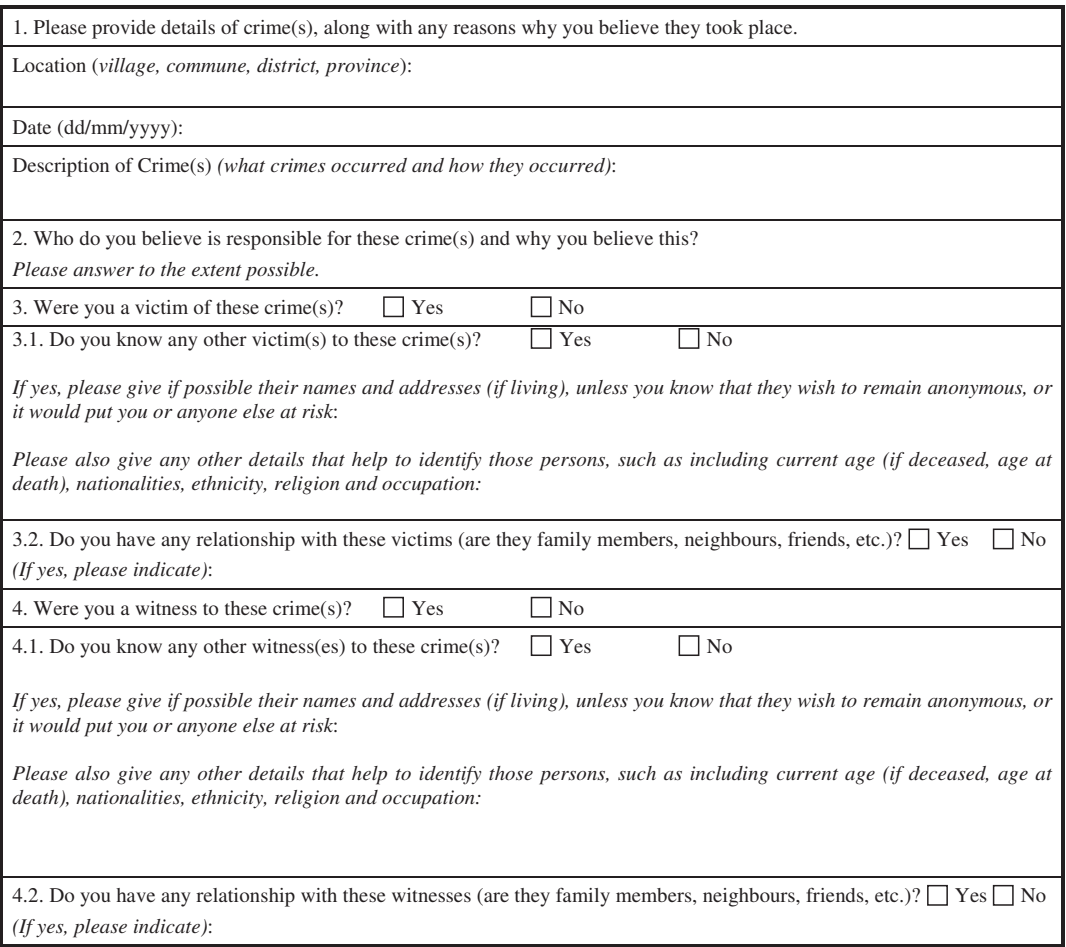




\section{Appendix B}

5. Your safety: Do you fear any specific negative consequences for yourself or for anyone named in this form as a result of filling it in and sending it to the ECCC? $\square$ Yes $\square$ No

If so, please explain exactly what your fears are:

\section{PART C}

\section{APPLICATION TO BE JOINED AS A CIVIL PARTY}

You should only complete this Part if you wish to be joined as a Civil Party to a judicial investigation

In order for the Court to accept you as a Civil Party, the injury you suffered must be: a) physical, material or psychological; b) the direct consequence of the offence, personal and have actually come into being. If your claim does not prove your identity and provide sufficient detail on the harm you suffered, it may be rejected by the Court's judges. For information on the connection between this harm and the crimes being investigated by the ECCC that needs to be shown, please contact the Victims Support Section.

1. Please indicate the proceedings to which you wish to be joined:

Case File No:

2. Please state the injury, loss or harm you have suffered, and give a brief description (such as physical injury, mental pain and anguish, loss of or damage to property):

\begin{tabular}{lcc}
\hline 3. Were you examined by a doctor after the event or events occurred? & $\square$ Yes & $\square$ No \\
\hline 4. Did you receive any medical or psychological treatment? & $\square$ Yes & $\square$ No \\
\hline 5. If yes, do you have any records regarding any medical or psychological treatment? & $\square$ Yes \\
If
\end{tabular}

If yes, please tick as appropriate and provide a photocopy, if available.

$\square$ Medical report from doctor, hospital or health centre $\quad \square$ X-rays $\quad \square$ Prescriptions/Invoices for medicines $\square$ Other. Please specify:

6. Does your condition persist today? $\square$ Yes $\square$ No

If yes, please give details:

7. In respect of material or property loss, please provide any further details or physical records that help identify the extent of loss suffered:

8. Do you have any preference as to the form of collective or moral reparation that you would like to obtain? $\square$ Yes $\square$ No

If yes, please give details:

\section{PART D}

\section{SIGNATURES}

\section{SIGNATURE OF THE VICTIM}

Please sign or add your thumbprint and date this Form, whether or not someone is acting on your behalf or assisting you in filling in this Form.

I hereby declare that:

- To the best of my knowledge and belief, the information I have given in the present Form is correct, otherwise I will be liable under the applicable law.

- I wish to participate in the proceedings before the ECCC by submitting this complaint.

$\square$ In addition to submitting this complaint I also wish to be joined as a Civil Party.

If you apply for Civil Party participation, please tick the box above and ensure that you have filled in Part C of the form.

Location:

$$
\text { Day: Month: Year: }
$$




\title{
Appendix B
}

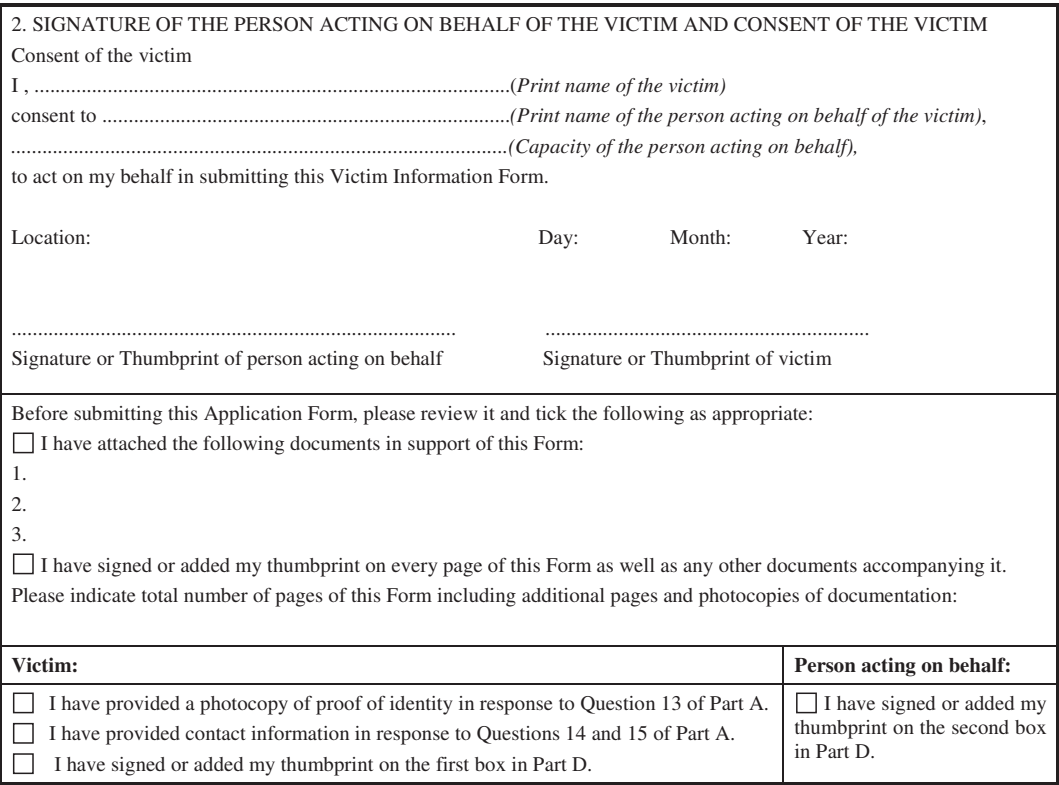

\section{NOTE}

Once the ECCC receives your Form, you will receive an acknowledgement. This acknowledgement will provide you with a registration number that you should use when communicating with the Court. If you send additional information to the Court, please use this registration number to ensure your application is properly updated. Please note that criminal proceedings take time and it may be a while before the ECCC judges make a decision on your application. This Form and the process of applying are free of charge. The Victims Support Section may be contacted at the address below:

\author{
Victims Support Section \\ ECCC Information Centre \\ No. 6A, Street 21, \\ Sangkat Tonle Basac I, Khan Chamcarmon, \\ Phnom Penh, Cambodia \\ Email: vss@eccc.gov.kh \\ Tel: +(855) 023214291 \\ Fax: +(855) 023214295
}

